\title{
Número especial: III Jornada de Comptabilitat i Direcció d'Empreses
}

\author{
Joaquim Rabaseda Tarres \\ President de l'Agrupació de Professors de Comptabilitat $i$ \\ Control i Membre de la Junta Directiva de I'ACCID (Spain) \\ joaquim.rabaseda@udg.edu
}

\begin{abstract}
L'any passat la revista Intangible Capital va publicar un número especial on es recollien els millors treballs de recerca sobre comptabilitat i direcció d'empreses presentats en el V Congrés de I'ACCID. Enguany la revista recull els treballs més destacats que s'han presentat en la III Jornada de Comptabilitat i Direcció d'Empreses, celebrat a Girona el passat 30 de maig. La Jornada, igual que el congrés, se celebra bianualment els anys en què no hi ha el congrés. Té un caràcter itinerant amb l'objectiu de fer palesa la presència de l'associació a tota la geografia catalana. El seu format és semblant al del congrés però amb una extensió més reduïda i ha acollit els diferents professionals que duen a terme una activitat orientada cap al desenvolupament de la comptabilitat i demés aspectes relatius a la direcció empresarial.
\end{abstract}

La Jornada també ha acollit la III Jornada de I'Agrupació de Professors de Comptabilitat de Catalunya, en la qual han concorregut un bon nombre d'acadèmics, per posar en comú i compartir coneixements i experiències en aquest camp.

Els treballs seleccionats són treballs originals que s'han presentat en les diferents sessions de treball o tallers de comunicacions. Prèviament han estat revisats pel Comitè Científic de la Jornada i després pel Comitè Editorial de la revista. Tracten sobre diverses temàtiques relacionades amb la Comptabilitat i la Direcció i constitueixen noves aportacions al coneixement propi del camp esmentat.

En primer lloc, hi ha un treball que s'ocupa de l'estudi de l'aplicació dels Global Reporting Initiative per part de les companyies de I'IBEX-35. La metodologia segueix I'anàlisi multivariable dels principals components dels resultats, correlació i la seva agrupació jeràrquica. En segon Iloc, es presenta un treball on es duu a terme l'anàlisi de les modificacions estatutàries per adaptar el règim de reemborsament del capital social a les normes comptables de les cooperatives. Un altre treball s'ocupa de l'anàlisi econòmica i financera de les grans indústries vinícoles de Catalunya durant el període que va de 2008 a 2012, amb l'objecte de valorar la projecció futura del sector i poder prendre les decisions econòmiques adequades. 
En quart lloc, es presenta un treball on, a partir d'una mostra de 750 empreses catalanes, es realitza una anàlisi comparativa de l'evolució de l'estructura econòmica i financera de les empreses familiars i les no familiars on la balança es decanta a favor de les primeres. Amb un objectiu semblant, el següent treball presenta un estudi dels factors d'èxit de les empreses de nova creació, on es posa l'accent en els factors financers que defineixen l'èxit de les empreses creades a Catalunya en els últims cinc anys.

El número de la revista es tanca amb dos treballs més. El primer d'ells preocupa per determinar, mitjançant una anàlisi comparativa de les empreses europees, en quina mesura les polítiques de benestar produeixen efectes en la rendibilitat de les empreses. El segon treball, fa una immersió en la literatura existent respecte la incertesa de l'empresa familiar per tal d'encarar el procés d'internacionalització, i ofereix possibles línies de recerca sobre aquesta temàtica.

Aquests són els treballs que s'inclouen en el present número de la revista, procedents de la III Jornada de I'ACCID, els quals s'espera que siguin de l'interès del lector. 